\title{
HYPERURICAEMIA IN POLYCYTHAEMIA VERA
}

BY

\author{
A. M. DENMAN, L. SZUR, and B. M. ANSELL \\ Departments of Medicine and Radiotherapy, Hammersmith Hospital, London
}

The association of hyperuricaemia and gout with polycythaemia vera has been known for many years and the frequency of these complications has been indicated in many large series (Lawrence, Berlin, and Huff, 1953; Wassermann, 1954). The high incidence of hyperuricaemia and gout was confirmed during a recent investigation into joint complaints in a series of patients with polycythaemia vera (Denman, Szur, and Ansell, 1964) in which gout was found in 18.7 per cent. and hyperuricaemia in 55 per cent. of the patients studied. However, hyperuricaemia and gout are not invariable features of polycythaemia vera and the reasons for this variation have not been clarified. Certain features of the disease have been reported to be particularly likely to produce hyperuricaemia, for example, immaturity of the white cell series (Stroebel and Law, 1956), and excessive megakaryocyte proliferation in the bone marrow and spleen (Hickling, 1958). According to Wassermann and Bassen (1959), hyperuricaemia is prominent when the disease has progressed to the stage of myelofibrosis. The present paper examines the relationship between the various aspects of the haemopoietic disorder and the hyperuricaemia.

\section{Material and Methods}

101 patients with polycythaemia vera, in whom the diagnosis had been made on the basis of a red cell volume estimation (R.C.V. greater than $35 \mathrm{ml} . / \mathrm{kg}$.) as well as on the peripheral blood count and bone marrow puncture, attended the Radiotherapy Department at Hammersmith Hospital during one 12-month period. Eight of these patients had developed myelosclerosis during the course of their disease, confirmed by bone biopsy. In a further ten patients, the possibility of this complication was suspected because of progressive splenic enlargement and changes in the morphology of the peripheral blood. Fourteen patients with platelet counts initially over $1,000,000$ per c.mm. were considered as belonging to the thrombocythaemic group. It should be emphasized that in all these groups the existence of $N$ polycythaemia vera was well established in the past. it

Blood specimens for the simultaneous determination of $\omega$ a full blood count, including the packed cell volume, red $\overrightarrow{0}$ cell, differential white cell, platelet, and reticulocyte $\frac{\text { ? }}{\partial}$ counts, and the serum urea and uric acid were obtained from 99 of the 101 patients. All 99 were examined $c$ clinically and, when palpable, the size of the spleen was estimated by measurement of its maximum extent below $\vec{c}$ the costal margin in the midclavicular line.

A number of special investigations were also available? from the patients' records. Red cell volume had been measured at the same time as the serum uric acid in 35 ? patients by the ${ }^{51} \mathrm{Cr}$ technique when the disease was first diagnosed. In 54 patients the serum uric acid had been estimated at the time that a sample of the bone marrow was obtained.

During the present study two 24-hour urate clearances $\overrightarrow{\overrightarrow{0}}$ were obtained from 52 patients who had been admitted to 3 hospital for assessment or for ${ }^{32} \mathbf{P}$ therapy. No dietary control was exercised over these patients, but the results of uric clearance were accepted only if the difference between the urate concentration of the two urate clearances was less than 15 per cent.; in some cases complete $\bar{\sigma}$ collection was verified by simultaneous creatinine clearances. Serum uric acid levels and blood counts were $i$ correlated in 24 patients at $1,3,6$, and 12 months after therapy with ${ }^{32} \mathbf{P}$ had been given.

\section{Results}

Taking the group as a whole, there was no correla-글. tion between the serum uric acid and any single $N$ feature of the blood count, whether this was the packed cell volume, white blood count, platelet $N$ count (Fig. 1), or reticulocyte count. Correlation $\omega$ was not improved if patients with active disease were considered separately, and there were no differences dependent on age and sex. In the fourteen patients $\overline{\mathscr{D}}$ considered to belong to the thrombocythaemic? group, the mean serum uric acid was $6 \cdot 1 \mathrm{mg}$. per cent. which was the same as in the series as a whole. $\frac{\vec{D}}{\mathbb{D}}$ In the eight patients with definite myelofibrosis, the $\frac{\rho}{\mathbb{D}}$ 


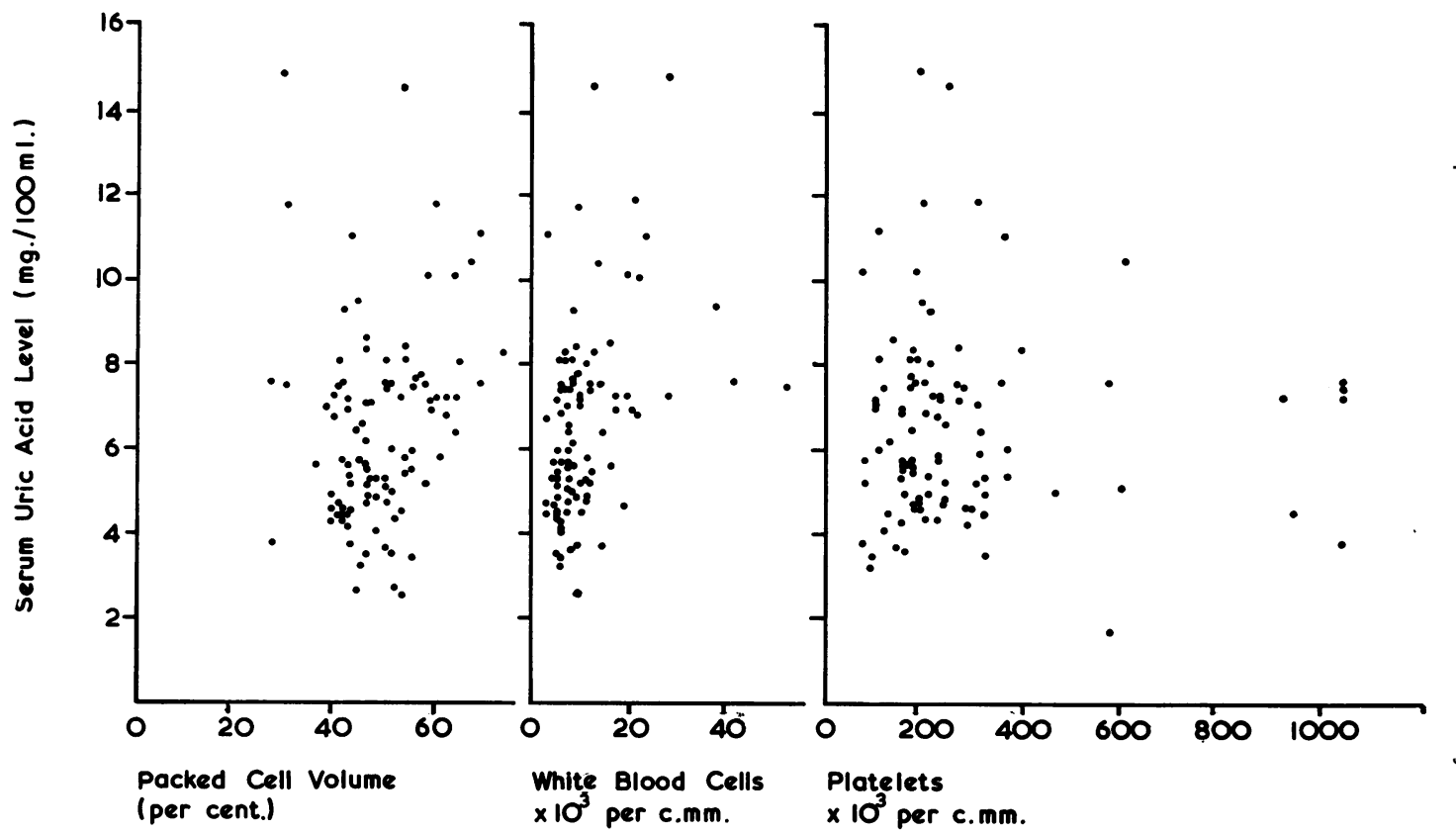

Fig. 1.-Lack of correlation of serum uric acid (mg. per cent.) and packed cell volume (P.C.V. per cent.), white blood count (W.B.C.), and platelet count in the group of 99 patients with polycythaemia vera.

mean serum uric acid of $11 \cdot 0 \mathrm{mg}$. per cent. was significantly higher than the mean value of the entire series $\left(\chi^{2}=34.6 ; P<0 \cdot 001\right)$. In the ten patients in whom this transition was suspected, the mean serum uric acid was also raised ( $7.5 \mathrm{mg}$. per cent.), but not to significant levels. Although the gross splenic enlargement found in most patients with myelofibrosis was commonly associated with hyperuricaemia, in the absence of this complication no correlation was found between splenic enlargement and serum uric acid. The red cell volume in the 35 patients in whom this had been performed, showed no significant correlation with the serum uric acid.

Bone Marrow.-To assess the bone marrow without prejudice, an equal number of films from patients with a variety of disorders were taken from the Haematology Department's files. The slides from the polycythaemic patients and the adjacent ones were selected. The films were mixed and examined with their identities masked. The myeloid erythroid ratio was determined on a differential count of 1,000 nucleated cells. A megakaryocytic index was devised to assess the degree of megakaryocytic proliferation. For this purpose, the cellular trails were examined by low-power microscopy and the average number of megakarycocytes seen in ten representative fields were graded as follows:

Grade 0 -Less than 1 per field;

Grades 1, 2, and 3-1, 2, or 3 per field;

Grade 4-More than 4 per field.

Even by these criteria no correlation could be found between the serum uric acid level and marrow morphology represented by the myeloid : erythroid $\overline{0}$ ratio and the megakarycocyte index.

Renal Function.-It is usually accepted that the normal urate clearance $\left(\mathrm{C}_{\mathrm{ua}}\right)$ is $8.7 \pm 2.5 \mathrm{ml} . / \mathrm{min}$. 근 in males and $9.2 \pm 2.7 \mathrm{ml} . / \mathrm{min}$. in females (Gutman $\frac{D}{O}$ and Yü, 1957). In the present study, $5 \mathrm{ml} . / \mathrm{min}$. was taken as the lower limit of normal; 26 of the $52 \mathrm{~N}$ patients studied were found to have a urate clearance below this level.

Patients with impaired urate clearance had serum $\omega$ uric acid levels higher than those in whom the clearance was normal $\left(\chi^{2}=52 \cdot 0 ;: \mathrm{P}<0.0001\right)$ (Fig. 2 , overleaf).

Defining uraemia as a blood urea of above $50 \mathrm{mg}$. per cent., eight of the 26 were uraemic, whereas elevated blood ureas were not found in patients with $\frac{}{\mathbb{D}}$ normal urate clearance. As would be expected, the $\frac{O}{\mathbb{Q}}$ 


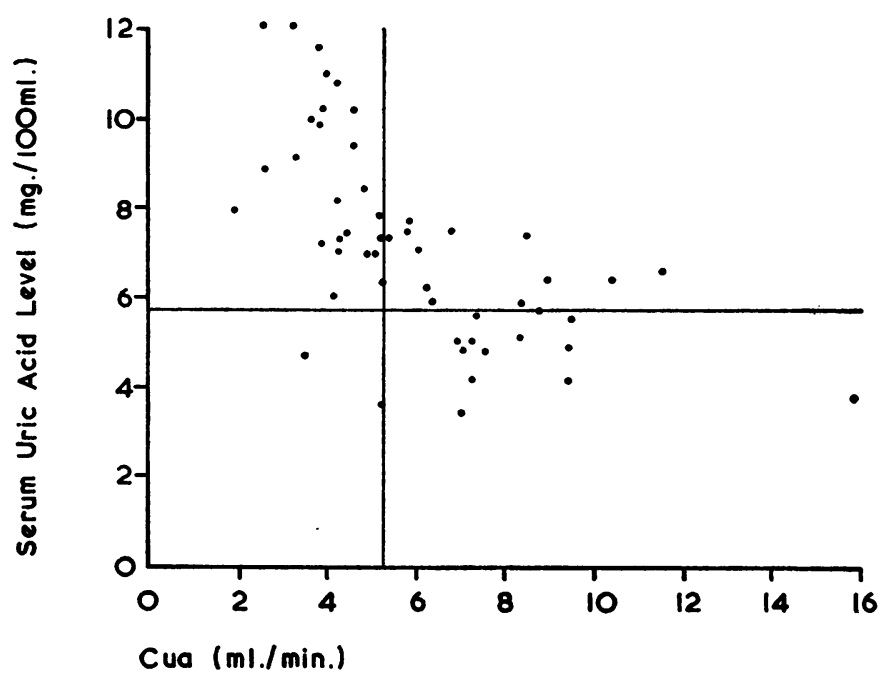

Fig. 2-Correlation of serum uric acid (mg. per cent.) and urate 0 clearance (mi./min.) in 52 patients with polycythaemia vera.

Cua (mI./min.)

total 24-hour urate output was considerably reduced in patients with impaired urate clearance. The urate clearance was measured in seven of the eight patients with myelofibrosis; in six it was below $5 \mathrm{ml} . / \mathrm{min}$., while in the remaining patient it was $5.2 \mathrm{ml}$./min. Thus, in this sub-group also, much of the rise in serum uric acid can be explained by the low urate clearance.

When the patients with normal and impaired urate clearance were taken as two separate groups and the peripheral blood count compared with serum uric acid, it was found that the serum uric acid and packed cell volume were now significantly and $\stackrel{ }{工}$ directly related in those patients in whom the urate clearance was normal (Fig. 3), but there was no such relationship between serum uric acid and the white cell count or the platelet count.

${ }^{32} \mathbf{P}$ [radioactive phosphorus] Therapy.-Changes in the serum uric acid were significantly related to reduction in the packed cell volume in the group of 24 patients who were followed after ${ }^{32} \mathrm{P}$ therapy (Table). None of these patients was uraemic or $\frac{O}{\Phi}$ suffering from myelofibrosis. A similar correlation could not be found between the white cell count or $\overline{\bar{o}}$

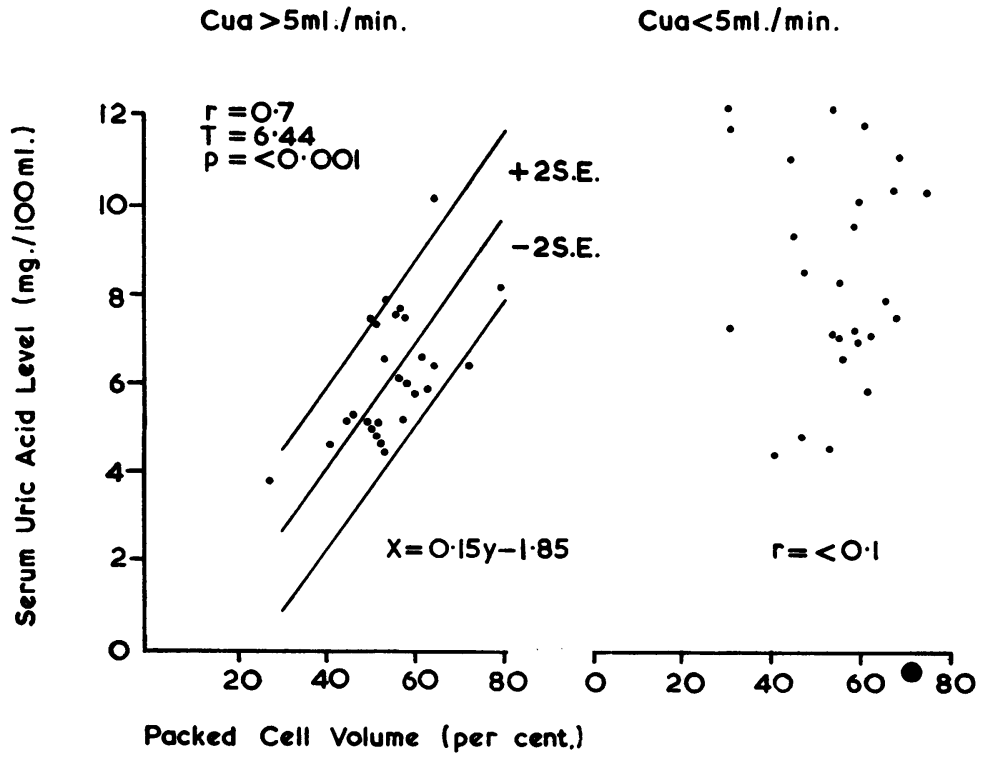

Fig. 3.-Correlation of serum uric acid (mg. per cent.) and packed cell volume (P.C.V. per cent.) in patients with normal urate clearance (Cua $>50$ $\mathrm{ml}$./min.) and lack of correlation in patients with relation in patients with (Cua $<5 \mathrm{ml} . / \mathrm{min}$.) 
platelet count and the serum uric acid. It is therefore suggested that the ${ }^{32} \mathrm{P}$ therapy influences the serum uric acid level mainly through its effect on erythropoiesis.

TABLE

RELATION BETWEEN FALL IN SERUM URIC ACID AND PACKED CELL VOLUME IN 24 PATIENTS AFTER ${ }^{32} \mathrm{P}$ THERAPY

\begin{tabular}{|c|c|c|c|c|c|}
\hline Months after Injection & 0 & 1 & 3 & 6 & 12 \\
\hline $\begin{array}{l}\text { Mean S.U.A. mg. per } \\
\text { cent. } \pm \text { I.S.D. }\end{array}$ & $\begin{array}{r}7 \cdot 1 \\
\pm 1 \cdot 7 \\
\end{array}$ & $\begin{array}{r}6 \cdot 0 \\
\pm 1 \cdot 5\end{array}$ & $\begin{array}{r}6 \cdot 1 \\
\pm 1 \cdot 5 \\
\end{array}$ & $\begin{array}{r}6 \cdot 1 \\
\pm 1 \cdot 4 \\
\end{array}$ & $\begin{array}{r}6 \cdot 5 \\
\pm 1 \cdot 8 \\
\end{array}$ \\
\hline $\begin{array}{l}\text { Mean P.C.V. mg. per } \\
\text { cent. } \pm \text { I.S.D. }\end{array}$ & $\begin{array}{r}59 \cdot 0 \\
\pm 6 \cdot 7\end{array}$ & $\begin{array}{r}52 \cdot 0 \\
\pm 7 \cdot 6\end{array}$ & $\begin{array}{r}50 \cdot 0 \\
\pm 7 \cdot 0\end{array}$ & $\begin{array}{r}50 \cdot 0 \\
\pm 7 \cdot 0\end{array}$ & $\begin{array}{r}52 \cdot 0 \\
\pm 6 \cdot 7\end{array}$ \\
\hline
\end{tabular}

\section{Discussion}

The results of the present survey make it clear that serum uric acid levels in polycythaemia are dependent on renal function as well as on the character and severity of the haematological disorder. When urate clearance is normal, the serum uric acid level can be correlated directly with the haematocrit. Correlation with the erythroid mass might have been even better if more red cell volume determinations had been made at the time the serum uric acid was estimated (Huber, Lewis, and Szur, 1964).

It is impossible to be sure whether the impaired renal clearance of urate preceded or was the result of the disease. A variety of renal lesions have been documented in association with polycythaemia (Brandt, Dacie, Steiner, and Szur, 1963; Rosse, Waldmann, and Cohen, 1963). In the high age groups in which this disease occurs, renal function is diminished (de Wardener, 1961) and the reduced glomerula filtration and tubular secretion (Davies and Shock, 1950) may affect urate clearance. This may well be of importance as the healthy kidney responds to an increased urate load by an increase in urate clearance (Nugent and Tyler, 1959). Conversely, a high incidence of renal disorders has been observed to develop in the course of polycythaemia vera (Videbaek, 1950; Chievitz and Thiede, 1962) and hyperuricaemia itself has been incriminated as a cause of chronic renal disease (Talbott and Terplan, 1960). It is possible that the increased blood viscosity resulting from high haematocrit levels might impede renal plasma flow and thereby reduce urate clearance.

Haematological features of polycythaemia vera traditionally incriminated with hyperuricaemia, such as immaturity of the white cell series and excessive megakaryocyte proliferation, could not themselves be correlated with marked hyperuricaemia unless accompanied by impaired urate clearance. Moreover, no correlation could be found between the white cell and platelet counts and the serum uric acid, when urate clearance was normal. Because of these alleged associations, particular care was given to the evaluation of marrow samples. However, normal serum uric acid figures were found even in patients with striking megakaryocytic proliferation and high myeloid : erythroid ratios, whilst no better correlation with megakaryocytic proliferation or myeloid immaturity could be found in 22 of the same patients from whom an iliac crest bone biopsy specimen had also been obtained.

Myelofibrosis is commonly accompanied by a moderate degree of hyperuricaemia (Lynch, 1962) which could result from increased nuclear catabolism consequent upon the ineffective erythropoiesis with excessive haemolysis of defective red cells found in this condition (Szur and Smith, 1961). The very high levels of serum uric acid in those patients who developed myelofibrosis could be accounted for by the associated impairment in urate clearance and may reflect the long course of the preceding polycythaemia vera (Wassermann, 1954).

An additional seven patients, presenting initially as cases of myelofibrosis confirmed by bone biopsy, were studied, in whom the disease had not been preceded by polycythaemia vera. The mean serum uric acid of this group was $6 \cdot 5+1 \cdot 7 \mathrm{mg}$. per cent., and the urate clearance was greater than $5 \mathrm{ml} . / \mathrm{min}$. in all seven of them.

After ${ }^{32} \mathbf{P}$ therapy the fall in uric acid was, in general, proportional to the fall in haematocrit. There was no evidence that those patients who had hyperuricaemia failed to respond to ${ }^{32} \mathrm{P}$, as has been suggested by Stroebel, Hall, and Pease (1951).

These findings suggest that the hyperuricaemia of polycythaemia vera results from a combination of "over-production" and "under-excretion", a situation similar to that seen in primary gout. Although excessive proliferation of red blood cell precursors with increased nuclear catabolism accounts for much of the hyperuricaemia (Yü, Weissmann, Sharney, Kupfer, and Gutman, 1956; Krakoff, Balis, Magill, and Nary, 1961), impaired renal excretion also contributes to its development.

\section{Summary}

Serum uric acid levels in 99 patients with polycythaemia vera have been reviewed in the light of their haematological features. Taking the group as a whole, correlation with the peripheral blood count was poor. Examination of the sternal marrow in 54 patients in whom contemporary serum uric acid 
figures were available did not support the concept that marked myeloid and megakaryocyte proliferations are more commonly associated with hyperuricaemia. Urate clearance estimations were performed in 52 patients; in 26 it was found to be impaired, and this included eight with uraemia, two of whom also had gout, and the six other patients with clinical gout. The mean level of serum uric acid in this group was $8.8 \mathrm{mg}$. per cent. compared with $6.3 \mathrm{mg}$. per cent. in those with a normal urate clearance; the level of the serum uric acid was significantly related to the packed cell volume in the patients with normal urate clearance.

It is suggested that the hyperuricaemia associated with polycythaemia is related to the over-production of uric acid as a result of the blood dyscrasia and that impaired renal function may cause further rises in the serum uric acid.

\section{REFERENCES}

Brandt, P. W. T., Dacie, J. V., Steiner, R. E., and Szur, L. (1963). Brit. med. J., 2, 468.

Chievitz, E., and Thiede, T. (1962). Acta med. scand., $179,513$.

Davies, D. F., and Shock, N. W. (1950). J. clin. Invest., 29, 496.

Denman, A. M., Szur, L., and Ansell, B. M. (1964). Ann. rheum. Dis., 23, 139.

Gutman, A. B., and Yü, T. F. (1957). Amer. J. Med., 23, 600 .

Hickling, R. A. (1958). Lancet, 1, 175.

Huber, H., Lewis, S. M., and Szur, L. (1964). Brit. J. Haemat., 10, 567.

Krakoff, I. H., Balis, M. E., Magill, J. W., and Nary, D. (1961). Med. Clin. N. Amer., 45, 521.

Lawrence, J. H., Berlin, N. I., and Huff, R. C. (1963). Medicine (Balt.), 32, 323.

Lynch, E. C. (1962). Arch. intern. Med., 109, 639.

Nugent, C. A., and Tyler, F. H. (1959). J. clin. Invest., $38,1890$.

Rosse, W. F., Waldmann, T. A., and Cohen, P. (1963). Amer. J. Med., 34, 76.

Stroebel, C. F., Hall, B. E., and Pease, G. L. (1951). J. Amer. med. Ass., 146, 1301.

- and Law, W. M. (1956). Med. Clin. N. Amer., 40, 1045.

Szur, L., and Smith, M. D. (1961). Brit. J. Haemat., 7, 147.

Talbott, J. H., and Terplan, K. L. (1960). Medicine (Balt.), 39, 405.

Videbaek, A. (1950). Acta med. scand., 138, 179.

Wasserman, L. R. (1954). Bull. N.Y. Acad. Med., 30, 343.

—_ and Bassen. F. (1959). J. Mt. Sinai Hosp. 261.
Yü, T. F., Weissmann, B., Sharney, L., Kupfer, S., and $\rightrightarrows$ Gutman, A. B. (1956). Amer. J. Med., 21, 901. Wardener, H. E. de (1961). "The Kidney", 2nd ed." p. 76. Churchill, London.

\section{L'hyperuricémie dans la maladie de Vaquez}

\section{RÉSUMÉ}

On a considéré les taux de l'acide urique dans le sérumîn de 99 patients atteints de maladie de Vaquez à la lumière de. leurs caractères hématologiques. Pris dans sa totalité, la P corrélation dans ce groupe avec la numération globulaire du sang périphérique a été faible. L'examen de la moelleు sternale de 54 malades, pour lesquels les chiffres conotemporaires de l'acide urique sanguin étaient disponibles ne vient pas à l'appui de l'hypothèse que la prolifération myéloide et mégacaryocytaire soit habituellement associéêr à l'hyperuricémie. On a procédé à la détermination de lạ̊ clearance de l'urate chez 52 malades; chez 26 d'entre euxw elle était diminuée, mais ce chiffre comprenait huit cas d'urémie, dont deux se trouvaient aussi atteints de goutte et six autres malades souffrant de goutte franche. Le taux moyen de l'uricémie dans ce groupe était de 8,8 pour cent tandis que chez ceux à la clearance uratique normale if n'était que de 6,3 pour cent; le taux de l'acide uriqưe sanguin avait un rapport significatif à la valeur hématocrite chez des malades à la clearance de l'urate normale.

On pense que l'hyperuricémie associée à la polycythémi民 depend de la production excessive de l'acide urique cone sécutive à la dyscrasie sanguine et que la fonction rénalę affaiblie peut faire augmenter davantage le taux de l'acide urique sanguin.

\section{La hiperuricemia en la policitemia vera}

\section{SUMARIO}

Se consideraron las cifras del ácido úrico en el suero de 99 enfermos con policitemia vera a la luz de sus rasgęs hematológicos. El grupo, en su totalidad, reveló pocà correlación con el recuento globular en la sangre periféricâ El cuadro de la médula esternal de 54 enfermos, para lơ cuales existieron cifras del ácido úrico contemporáneas no apoya la hipótesis de que la proliferación mieloide $\vec{\exists}$ megacariocitaria se vea asociada habitualmente con 18 hiperuricemia. El clearance del urato fué determinada en 52 enfermos; se notaron cifras bajas en 26 de ellos, pero ocho de estos sufrían de uremia asociada a la gota en do casos; otros seis enfermos padecían gota franca. Las cifras medias de uricemia en este grupo fueron de un 8,8 pơ ciento mientras que en enfermos con un clearance urátic $\theta$ normal estas cifras fueron de un 6,3 por ciento. Se observy una correlación significativa entre las cifras del ácido úrico en el suero y el volumen corpuscular en los enfermos con el clearance urático normal.

Se sugiere que la hiperuricemia asociada a la policitemia depende de la producción excesiva del ácido úricé consecutiva a la discrasia sanguínea y que la función renal debilitada puede ocasionar un aumento adicional de्ç ácido úrico en la sangre. 